\title{
Lohusaların Obstetrik Öykülerinin Doğum Sonu Bebeklerin Beslenme Şekillerine Etkisi
}

\section{The Effect of Puerperant's Obstetric Histories on Infants Feeding Methods in the Postpartum Period}

\author{
${ }^{1}$ Emine İbici Akça, ${ }^{2}$ Ayşe Şenoğlu, ${ }^{3}$ Şule Gökyıldız Sürücü ${ }^{4}$ Melike Öztürk
}

ÖZET

Giriș: Emzirmeyi etkileyen olumsuz faktörlerin ortaya çıkarılması ve bu faktörlere yönelik gerekli önlemlerin alınması doğum sonu dönemde bebeklerin anne sütü ile beslenmelerinin başlatılmasında ve sürdürülmesinde önemlidir. Bu araştırma lohusaların obstetrik öykülerinin doğum sonu bebeklerin beslenme șekillerine etkisini incelemek amacıyla yapılmıștır. Yöntem: Analitik-kesitsel tipte olan bu araștırma Ocak-Haziran 2017 tarihleri arasında bir kadın doğum hastanesinin kadın doğum yoğun bakım ve doğum servislerinde yürütülmüştür. Araştırmanın örneklemini 135 lohusa oluşturmuştur. Araștırmada veriler araștırmacıların literatür doğrultusunda hazırlamıs olduğu 'Lohusa Tanıtım Formu' ile toplanmıștır. Veriler Statistical Package for Social Sciences for Windows 20.0 istatistik paket programında sayı, yüzde dağılımları, ortalama, standart sapma ve ki kare testleri kullanılarak analiz edilmiștir. Bulgular: Lohusaların yaş ortalaması 26.81土6.568 (min:16, max:47)'dir. Lohusaların \%38.5'i kadın doğum yoğun bakım servisinde yatmakta ve \%69.6'sının yatış süresi 1 gündür. Lohusaların \%49.6'sının bir çocuk sahibi olduğu, \%68.9'unun normal doğum yaptığı ve \%15.6'sının doğum sonu bakıma ilişkin eğitim aldığı belirlenmiştir. Lohusaların sosyo-demografik özellikleri ile doğum sonu bebeğini sadece anne sütü ile besleme durumları arasında istatistiksel olarak anlamlı bir fark bulunmamıştır ( $>>0.05)$. Lohusaların yattıkları servis, yatış süreleri, çocuk sayıları, doğum şekilleri ve doğum sonu bakıma ilişkin eğitim alma durumları ile doğum sonu bebeğini sadece anne sütü ile besleme durumları arasında istatistiksel olarak anlamlı bir fark saptanmıştır $(\mathrm{p}<0.05)$. Sonuç: Doğum servisinde yatma, doğum sonu hastanede kalış süresinin kısa olması (1 gün), birden fazla çocuğa sahip olma, normal doğum yapma ve doğum sonu bakıma ilişkin eğitim alma lohusaların doğum sonu bebeğini sadece anne sütü ile besleme oranlarını arttırmaktadır.

Anahtar Sözcükler: Lohusa, Bebek, Doğum sonu, Anne sütü, Besleme

\begin{abstract}
Background: It is important to reveal the negative factors that affect breastfeeding and to take the necessary precautions for these factors in the initiation and maintenance of breastfeeding of babies in the postpartum period. This study was conducted to examine the effect of obstetric histories of puerperant on the feeding patterns of babies in the postpartum period. Methods: The study, which is of analytical-cross-sectional type, was carried out between January and June 2017 in a obstetrics intensive care unit and maternity clinics of a maternity hospital. The sample of the study consisted of 135 puerperants. The data were collected with the 'Puerperant İnformation Form' prepared by the researchers in line with the literature. Data was analyzed by number, percentage distributions, mean, standard deviation and Chi square tests using Statistical Package for Social Sciences for Windows 20.0 program. Results: The mean age of the puerperants was $26.81 \pm 6.568$ ( $\min : 16$, max:47). $38.5 \%$ of the puerperants were hospitalized in the obstetrics intensive care unit, and $69.6 \%$ had a hospital stay of 1 day. It was determined that $49.6 \%$ of the puerperants had one child, $68.9 \%$ had normal births and $15.6 \%$ had postpartum care training. There was no statistically significant difference between the socio-demographic characteristics of the puerperants and their breastfeeding status ( $\mathrm{p}>0.05)$. A statistically significant difference was found between the clinic, length of stay, children's numbers, delivery methods and receiving postpartum care training of the puerperants and breastfeeding with only breast milk of their babies in the postpartum period $(\mathrm{p}<0.05)$. Conclusion: Maternity unit, shorter postpartum hospital stay, having more than one child, giving birth to normal birth and recieving postnatal care training increase the rate of feeding with breastfeeding only in the postpartum period.
\end{abstract}

Key words: Puerperant, Baby, The Postpartum Period, Breastfeeding, Feeding

Received / Geliştarihi: 13.03.2021, Accepted / Kabul tarihi: 09.05.2021

${ }_{1}^{1}$ Amasya Üniversitesi Sağlık Bilimleri Fakültesi Ebelik Bölümü, Amasya/Türkiye, e_mail: emineeibici@gmail.com, ORCID: 0000-0001-5432-2951

${ }^{2}$ Sağlık Bakanlığı Adana Il Sağlık Müdürlüğü Acil Sağlık Hizmetleri Başkanlığı, Adana/Türkiye, e_mail: aysenoglu@gmail.com, ORCiD: 0000-0003-05801758

${ }^{3}$ Çukurova Üniversitesi Sağlık Bilimleri Fakültesi Ebelik Bölümü, Adana/Türkiye, e_mail: gokyildizsule@gmail.com, ORCİD: 0000-0002-0088-4219

${ }^{4}$ Çukurova Üniversitesi Sağlık Bilimleri Fakültesi Ebelik Bölümü, Adana/Türkiye, e_mail: mozturk@cu.edu.tr, ORCID: 0000-0001-9452-4873

*Address for Correspondence / YazışmaAdresi:

Amasya Üniversitesi Sağlık Bilimleri Fakültesi Ebelik Bölümü İpekköy/AMASYA

e-posta: emineeibici@gmail.com

İbici Akça E, Şenoğlu A, Gökyıldız Sürücü Ş, Öztürk M. Lohusaların Obstetrik Öykülerinin Doğum Sonu Bebeklerin Beslenme Şekillerine Etkisi. TJFMPC, 2021;15(3): 501-509.

DOI: $10.21763 /$ tjfmpc.896239 


\section{GÍRIŞ}

Lohusalık dönemi emzirme sürecini de içine alan kadın yaşamının önemli dönemlerindendir. Emzirme, hem anneye hem de çocuğa yararları olan gebelik ve doğum süreçlerinin doğrudan ve doğal sonucu olarak gelişen fizyolojik bir olaydır. Günümüzde, emzirmenin faydalarının emzirme süresi ile sınırlı olmayıp uzun vadede yaşam kalitesine yansımalarıyla yetişkin yaşamına kadar uzandığ 1 düşünülmektedir. ${ }^{1}$

Anne ve bebek sağlığının korunması ve geliștirilmesinde anne sütü ile beslenmenin etkisi oldukça fazladır. ${ }^{2-4}$ Anne sütü bebeğin sağlıklı büyümesi ve gelişmesi için ihtiyaçları doğrultusunda üretilen maliyetsiz doğal bir besindir. Aynı zamanda anne sütü ile beslenmenin, bağışıklık sistemini güçlendirerek bebeği birçok hastalıktan koruduğu, bazı hastalıkların görülme sıklığını azalttığ 1 bilinmektedir. ${ }^{2}$ Bunun yanı sira anne sütü ile beslenmenin çocuk ruh sağlı̆̆ ve gelişimi üzerine olumlu katkılarının olduğu bildirilmektedir. ${ }^{4}$ Emzirmenin anne için de sayısız yararları söz konusudur. Emzirmenin erken dönemde uterus involüsyonu, doğum sonu kanama ve enfeksiyon riskinde azalma, laktasyonel amenore, hizlı kilo verme, beden imajında iyileşme, doğum sonu depresyon, stres ve anksiyetede azalma gibi yararları söz konusudur. Uzun dönemde ise emzirmenin, meme kanseri, over kanseri, endometriyum kanseri, endometriyozis, diabetes mellitus, osteoporoz, kardiyovasküler hastalıklar, metabolik sendrom, romatoid artrit, alzheimer ve multiple skleroz gibi hastalıklardan koruduğu bildirilmektedir. ${ }^{1,3,5}$

Dünya Sağlık Örgütü (DSÖ) ve Birleșmiş Milletler Çocuklara Yardım Fonu (UNICEF) doğumdan sonraki ilk bir saat içerisinde emzirmeye başlanılmasını ve bebeklerin yaşamın ilk altı ayı boyunca sadece anne sütü ile beslenmesini, altıncı aydan itibaren iki yaşına kadar anne sütüne ilave uygun tamamlayic1 gidalarla beslenmeyi önermektedir. ${ }^{6,7}$ DSÖ altı aydan küçük bebeklerin $\% 40$ 'ının sadece anne sütü ile beslendiğini bildirmiștir. ${ }^{8}$ Ülkemizde ise sadece anne sütü ile beslenen altı aydan küçük bebeklerin oranının $\% 41$ olduğu ve sadece anne sütü alanların ortanca emzirilme süresinin 1.8 ay olduğu bildirilmektedir. ${ }^{9}$ Doğum sonu erken dönemde emzirmeye başlama emzirme başarısını ve devamlılığını doğrudan etkilemektedir. ${ }^{10} \mathrm{Bu}$ nedenle lohusalık döneminde bebek beslenmesini etkileyen faktörlerin araştırılmasına ihtiyaç vardır.

Doğum sonu döneme ilişkin eğitim alma durumu kadınların emzirme davranışını olumlu etkilemektedir. ${ }^{11-13}$ Yaşamın ilk saatlerinde emzirmenin başlatılması ve sürdürülmesi konularında danışmanlık yapmak ve kadınları desteklemek ebe ve hemşirelerin önemli rolleri arasındadır. ${ }^{14}$ Ebe ve hemşireler tarafindan verilen danışmanlık hizmetlerinde kadınların bireysel farklılıklarının gözetilerek eğitim içeriğinin planlanması ve dönem dönem ebe ve hemşirelerin hizmet içi eğitimler alarak bilgilerini güncellemeleri bebeklerin anne sütü ile beslenmelerinde son derece önemlidir. ${ }^{13}$

Günümüzde emzirme üzerinde çok durulan bir konu olmasına rağmen emzirme oranları hala istenilen düzeyde değildir. Emzirmeye erken dönemde başlanılsa dahi ilk 6 ay sadece anne sütü ile beslenmeye devam etme oranları düşüktür. Literatürde emzirme ve emzirmeyi sürdürmedeki başarısızlık nedenleri arasında emzirmeye ilişkin bilgi eksikliği, doğum şekli, yenidoğanın sağlık durumu, meme sorunları, ilaç kullanımı, alkol, sigara kullanımı gibi birçok faktör yer almaktadır. ${ }^{15,16}$ Literatürde ilk 6 ay sadece anne sütü ile beslenmeyi etkileyen faktörlerin incelendiği çalışmalar mevcuttur. ${ }^{2,16}$ Yeşilçiçek Çalık ve ark. (2017) çalışmalarında bazı obstetrik özelliklerin ilk 6 ay bebeklerin sadece anne sütü ile beslenme durumlarını etkileyebileceğini bildirmiştir. ${ }^{14} \mathrm{Bu}$ sonuç lohusaların obstetrik özelliklerinin doğumdan hemen sonra bebeklerini sadece anne sütü ile besleme davranışı ile ilgili merak uyandırmaktadır. Doğum sonu dönemde emzirmeyi olumsuz yönde etkileyen faktörlerin çalışmalarla ortaya çıkarılması ve bu faktörlere yönelik gerekli önlemlerin alınması gerekmektedir. Lohusaların obstetrik öykülerinin doğum sonu bebeklerin beslenme şekillerine etkisinin değerlendirilmesi amacıyla yapılan bu araştırmanın doğum sonu dönemde anne sütüne erken başlanması ve sadece anne sütü ile beslenmenin sürdürülmesinde danışmanlık hizmeti veren ebelere katkı sağlaması hedeflenmektedir.

\section{YÖNTEM}

\subsection{Amaç ve Araştırmanın Türü}

$\mathrm{Bu}$ araştırma lohusaların mevcut gebelik ve doğuma ait özelliklerinin doğum sonu bebeklerin beslenme şekillerine etkisini incelemek amacıyla analitikkesitsel olarak yapılmıştır.

\subsection{Araştırmanın Evreni ve Örneklemi}

Araştırmanın evrenini Ocak - Haziran 2017 tarihleri arasında bir kadın doğum hastanesinin kadın doğum yoğun bakım ve doğum servislerinde yatan lohusaları oluşturmuştur. Örneklemi ise belirtilen tarihlerde ilgili kliniklerde en az 1 gün süre ile yatan ve araştırmaya katılmayı gönüllü olarak kabul eden 135 lohusa oluşturmuştur. "En az 1 gün süre ile yatan" ifadesi, sadece veri toplanıldığı esnada hastanın gün bazında ilgili klinikte yattığı süreyi 
kapsamaktadır. İlgili hastanede normal doğum sonrası 24 saat; sezaryen sonrası 48 saat hastanede kalma zorunluluğu bulunmakla birlikte bazı durumlarda hastalar imza atarak ve sorumluluk alarak kendileri hastanede kalmak istemedikleri için yatış süresi dolmadan çıkabilmektedir. Ayrıca, doğum sonrasında, yoğun bakım ihtiyacı olan hastalar önce kadın doğum yoğun bakım ünitesine alınmakta, durumu stabil olunca doğum servisine çıkışı yapılmaktadır. Bu durumda da yatış süresi, hastanın sadece yoğun bakım ünitesinde kalıș süresini yansıtmaktadır. Araştırmaya alınan lohusalar ilgili tarihlerde belirtilen servislerde yatan lohusalar arasından basit rastgele örnekleme yöntemi ile seçilmiştir.

\subsection{Veri Toplama Form ve Araçları}

Lohusa Tanıtım Formu: Araştırmacılar tarafından literatür taranarak lohusaların bebeklerini besleme şekillerini etkileyen faktörleri belirlemeye yönelik hazırlanmıştır. Form sosyo-demografik özellikleri içeren 15 ve obstetrik özelliklere ilişsin 20 olmak üzere toplam 35 sorudan oluşan bir formdur. ${ }^{14,17-19}$

\section{4 İstatistiksel Analiz}

Toplanan veriler "Statistical Package for Social Sciences" (SPSS) for Windows 20.0 istatistik paket programında tanımlayıcı istatistikler (sayı, yüzde dağılımları, ortalama, standart sapma) ve karşılaştırmalı analizle ki kare testleri kullanılarak analiz edilmiştir. $\mathrm{p}<0.05$ düzeyindeki değerler istatistiksel olarak anlamlı kabul edilmiştir.

\subsection{Araştırmanın Etik Yönü}

Çalışmanın yapılabilmesi için Çukurova Üniversitesi Tıp Fakültesi Girişimsel Olmayan Klinik Araştırmalar Etik Kurulundan etik onay (Karar No:25/13 Ocak 2017), araştırmanın yapıldığ1 hastaneden kurum izni ve katılımcilardan bilgilendirilmiş onam alınmıştır.

\section{BULGULAR}

Lohusaların yaş ortalaması 26.81 \pm 6.568 (min:16, max:47)'dir. Lohusaların \%28.9'unun eğitim düzeyinin okuryazar ve altı olduğu, \%71.1'inin çekirdek aileye sahip olduğu, \%50.4'ünün ekonomik düzeyini orta olarak değerlendirdiği ve \%73.3'ünün sosyal güvencesinin bulunmadığ1 belirlenmiştir. Lohusaların \%10.4'ünün sigara kullandığı saptamıştır (Tablo 1).
Tablo 1. Lohusaların sosyo-demografik özelliklerinin dağılımı

\begin{tabular}{|c|c|c|}
\hline Sosyo-demografik özellikler & $\begin{array}{c}\text { Ort. } \pm \\
\text { SS }\end{array}$ & $\begin{array}{l}\text { Min-Max } \\
\text { Değerler }\end{array}$ \\
\hline \multicolumn{3}{|l|}{ Lohusaların yaș ortalaması } \\
\hline \multirow[t]{2}{*}{$26.81 \pm 6.568 \quad 16-47$} & & \\
\hline & $\mathbf{n}$ & $\%$ \\
\hline \multicolumn{3}{|l|}{ Eğitim durumu } \\
\hline Okuryazar ve altı & 39 & 28.9 \\
\hline İlkokul & 35 & 25.9 \\
\hline Ortaokul & 30 & 22.2 \\
\hline Lise ve üzeri & 31 & 23.0 \\
\hline \multicolumn{3}{|l|}{ Aile tipi } \\
\hline Çekirdek aile & 96 & 71.1 \\
\hline Geniş aile & 39 & 28.9 \\
\hline \multicolumn{3}{|l|}{ Ekonomik durum algısı } \\
\hline Düşük & 67 & 49.6 \\
\hline Orta & 68 & 50.4 \\
\hline \multicolumn{3}{|l|}{ Sosyal güvence } \\
\hline Var & 99 & 73.3 \\
\hline Yok & 36 & 26.7 \\
\hline \multicolumn{3}{|l|}{ Sigara kullanma durumu } \\
\hline Kullanan & 14 & 10.4 \\
\hline Kullanmayan & 121 & 89.6 \\
\hline Toplam & 135 & 100.0 \\
\hline
\end{tabular}

Lohusaların \%38.5'inin yattığ doğum yoğun bakım servisi olup \%69.6'sının yatış süresi 1 gündür. Lohusaların \%50.4'ünün birden fazla çocuğa sahip olduğu, \%68.9'unun normal doğum yaptığı ve \%34.6'sının iki doğum arası süresinin iki yıldan az olduğu belirlenmiştir. Lohusaların \%80.0'inin gebeliğinin planlı olduğu ve \%15.6'sının doğum sonu bakıma ilişkin eğitim aldığı saptanmıștır (Tablo 2).

Tablo 2. Lohusaların obstetrik özelliklerinin dağ 1 lımı

\begin{tabular}{lcc}
\hline Obstetrik özellikler & n & \% \\
\hline Yattığı servis & & \\
\hline Kadın doğum yoğun bakım & 52 & 38.5 \\
Doğum servisi & 83 & 61.5 \\
\hline Yatış süresi & & \\
\hline 1 gün & 94 & 69.6 \\
2 gün & 31 & 23.0 \\
3 gün & 10 & 7.4 \\
\hline Çocuk sayısı & & \\
\hline Bir çocuk & 67 & 49.6 \\
Birden fazla çocuk & 68 & 50.4 \\
\hline Doğum şekli & \\
\hline Normal doğum & 93 & 68.9 \\
Sezaryen & 42 & 31.1 \\
\hline İki doğum arası süre (n=81) & & \\
\hline 2 yıldan az & 28 & 34.6 \\
2 yıl ve üzeri & 53 & 65.4 \\
\hline Gebeliğin planlı olma durumu & \\
\hline Planlı & & \\
Plansız & 108 \\
\hline Doğum sonu bakıma ilişkin eğitim & 21 & \\
alma durumu & & \\
\hline Alan & & \\
Almayan & & \\
\hline & & \\
\hline
\end{tabular}


Lohusaların bebeklerinin \%56.3'ünün cinsiyetinin k1z olduğu, \%51.9'unun doğum kilosunun 3000 gr üzeri olduğu, \%3.0'ünün doğum sonu ilk 30 dakika içerisinde emzirmeye başlanıldığı (tamamı normal doğum yapan lohusalar) ve \%20.7'sinin doğum sonu yenidoğan yoğun bakımda kaldığı belirlenmiştir (Tablo 3).
Lohusaların sosyo-demografik özellikleri (eğitim durumu, aile tipi, ekonomik durum, sosyal güvence) ile doğum sonu bebeklerini besleme şekilleri karşılaştırılmıştır. Lohusaların sosyodemografik özellikleri ile doğum sonu bebeklerini besleme şekilleri arasında istatistiksel olarak anlamlı bir fark saptanmamıştır ( $\mathrm{p}>0.05)$ (Tablo 4).

Tablo 3. Lohusaların bebeklerinin bazı özellikleri

\begin{tabular}{lcc}
\hline Özellikler & n & \% \\
\hline Cinsiyet & & 56.3 \\
\hline K1z & 76 & 43.7 \\
Erkek & 59 & \\
\hline Doğum kilosu & 65 & 48.1 \\
\hline 3000 gr ve altı & 70 & 51.9 \\
3000 gr üzeri & & 3.0 \\
\hline Doğum sonu ilk emzirilme zamanı & 4 & 97.0 \\
\hline Ḟ̉lk 30 dakika & 131 & 20.7 \\
İlk 30 dakika sonrası & & 79.3 \\
\hline Doğum sonu yenidoğan yoğun bakımda kalma & 28 & $\mathbf{1 0 0 . 0}$ \\
\hline Kalan & 107 & $\mathbf{1 3 5}$ \\
Kalmayan & & \\
\hline Toplam & & \\
\hline
\end{tabular}

*Tamamı normal doğum yapmış lohusalar

Tablo 4. Lohusaların sosyo-demografik özelliklerine göre bebeklerini besleme şekillerinin karşılaştırılması

\begin{tabular}{|c|c|c|c|c|c|c|c|c|}
\hline \multirow{3}{*}{$\begin{array}{l}\text { Sosyo-demografik } \\
\text { özellikler } \\
\text { Eğitim durumu }\end{array}$} & \multicolumn{6}{|c|}{ Bebeklerin beslenme șekli } & \multirow{3}{*}{$\mathbf{X}^{2}$} & \multirow{3}{*}{$\mathbf{p}$} \\
\hline & \multicolumn{2}{|c|}{$\begin{array}{c}\text { Sadece anne } \\
\text { sütü }\end{array}$} & \multicolumn{2}{|c|}{ Diğer* } & \multicolumn{2}{|c|}{ Toplam } & & \\
\hline & $\mathbf{n}$ & $\%$ & $\mathbf{n}$ & $\%$ & $\mathbf{n}$ & $\%$ & & \\
\hline Okuryazar ve altı & 29 & 25.9 & 10 & 43.5 & 39 & 28.9 & & \\
\hline İlkokul & 31 & 27.7 & 4 & 17.4 & 35 & 25.9 & 5.778 & 0.123 \\
\hline Ortaokul & 28 & 25.0 & 2 & 8.7 & 30 & 22.2 & & \\
\hline Lise ve üzeri & 24 & 21.4 & 7 & 30.4 & 31 & 23.0 & & \\
\hline \multicolumn{9}{|l|}{ Aile tipi } \\
\hline Çekirdek aile & 80 & 71.4 & 16 & 69.6 & 96 & 71.1 & 0.032 & 0.857 \\
\hline Geniş aile & 32 & 28.6 & 7 & 30.4 & 39 & 28.9 & & \\
\hline \multicolumn{9}{|c|}{ Ekonomik durum algısı } \\
\hline Düşük & 52 & 46.4 & 15 & 65.2 & 67 & 49.6 & 2.695 & 0.101 \\
\hline Orta & 60 & 53.6 & 8 & 34.8 & 68 & 50.4 & & \\
\hline \multicolumn{9}{|l|}{ Sosyal güvence } \\
\hline Var & 83 & 74.1 & 16 & 69.6 & 99 & 73.3 & 0.201 & 0.654 \\
\hline Yok & 29 & 25.9 & 7 & 30.4 & 36 & 26.7 & & \\
\hline
\end{tabular}

*Diğer: Yalnızca mama alanlar ya da anne sütü ile birlikte mama alanlar $\quad \mathrm{X}^{2}$ : Ki kare testi 
Lohusaların obstetrik özellikleri ile doğum sonu bebeklerini besleme şekilleri arasında istatistiksel farklılıklar incelenmiştir. Lohusaların yattıkları servis, hastanede yatış süreleri, çocuk sayıları, doğum şekilleri ve doğum sonu bakıma ilişkin eğitim alma durumları ile doğum sonu bebeğini sadece anne sütü ile besleme durumları arasında istatistiksel olarak anlamlı bir fark saptanmıştır $(p<0.05)$. Doğum servisinde yatan lohusaların kadın doğum yoğun bakım servisinde yatanlara oranla, yatış süresi bir gün olan lohusaların yatış süresi iki veya üç gün olanlara oranla, birden fazla çocuğu olan lohusaların bir çocuğu olanlara oranla doğum sonu bebeklerini sadece anne sütü ile besleme oranları daha yüksek bulunmuştur. Ayrıca normal doğum yapan lohusaların sezaryen ile doğum yapanlara oranla, doğum sonu bakıma ilişkin eğitim alan lohusaların eğitim almayanlara oranla doğum sonu bebeklerini sadece anne sütü ile besleme oranları daha yüksek saptamıştır. Lohusaların gebeliklerinin planlı olma durumları ile doğum sonu bebeklerini besleme şekilleri arasında istatistiksel olarak anlamlı bir fark saptanmamştır ( $\mathrm{p}>0.05)$ (Tablo 5).

Tablo 5. Lohusaların obstetrik özelliklerine göre bebeklerini besleme şekillerinin karşılaştırılması

\begin{tabular}{|c|c|c|c|c|c|c|c|c|}
\hline \multirow{3}{*}{$\begin{array}{l}\text { Obstetrik özellikler } \\
\text { Yattı̆̆ } \text { I servis }\end{array}$} & \multicolumn{6}{|c|}{ Bebeklerin beslenme şekli } & \multirow{3}{*}{ Ki kare } & \multirow{3}{*}{$\mathbf{p}$} \\
\hline & \multicolumn{2}{|c|}{$\begin{array}{l}\text { Sadece anne } \\
\text { sütü }\end{array}$} & \multicolumn{2}{|c|}{ Diğer* } & \multicolumn{2}{|c|}{ Toplam } & & \\
\hline & n & $\%$ & $\mathbf{n}$ & $\%$ & $\mathbf{n}$ & $\%$ & & \\
\hline $\begin{array}{l}\text { Kadın doğum yoğun } \\
\text { bakım }\end{array}$ & 29 & 25.9 & 23 & 100.0 & 52 & 38.5 & 44.251 & 0.000 \\
\hline Doğum servisi & 83 & 74.1 & 0 & 0 & 83 & 61.5 & & \\
\hline \multicolumn{9}{|l|}{ Yatış süresi } \\
\hline 1 gün & 83 & 74.1 & 11 & 47.8 & 94 & 69.6 & & \\
\hline 2 gün & 23 & 20.5 & 8 & 34.8 & 31 & 23.0 & 7.310 & 0.026 \\
\hline 3 gün & 6 & 5.4 & 4 & 17.4 & 10 & 7.4 & & \\
\hline \multicolumn{9}{|l|}{ Çocuk sayısı } \\
\hline Bir çocuk & 49 & 43.8 & 18 & 78.3 & 67 & 49.6 & 9.091 & 0.003 \\
\hline Birden fazla çocuk & 63 & 56.2 & 5 & 21.7 & 68 & 50.4 & & \\
\hline \multicolumn{9}{|l|}{ Doğum şekli } \\
\hline Normal doğum & 88 & 78.6 & 5 & 21.7 & 93 & 68.9 & 28.757 & 0.000 \\
\hline Sezaryen & 24 & 21.4 & 18 & 78.3 & 42 & 31.1 & & \\
\hline \multicolumn{9}{|c|}{ Gebeliğin planlı olma durumu } \\
\hline Planl1 & 88 & 78.6 & 20 & 87.0 & 108 & 80.0 & 0.839 & 0.567 \\
\hline Plansiz & 24 & 21.4 & 3 & 13.0 & 27 & 20.0 & & \\
\hline \multicolumn{9}{|c|}{ Doğum sonu bakıma ilişkin eğitim alma durumu } \\
\hline Alan & 21 & 18.8 & 0 & 0 & 21 & 15.6 & 5.107 & 0.024 \\
\hline Almayan & 91 & 81.2 & 23 & 100.0 & 114 & 84.4 & & \\
\hline
\end{tabular}

*Diğer: Yalnızca mama alanlar ya da anne sütü ile birlikte mama alanlar $\quad \mathrm{X}^{2}$ : Ki kare testi

\section{TARTISMMA}

Lohusaların obstetrik öykülerinin doğum sonu bebeklerin beslenme şekillerine etkisini incelemek amaciyla analitik-kesitsel tipte yürütülen bu araştırmada, lohusaların doğum sonu bebeklerini sadece anne sütü ile beslemelerini; hastanede yattıkları servis, yatış süreleri, çocuk sayıları, doğum șekilleri ve doğum sonu bakıma ilișkin eğitim alma durumlarının etkilediği belirlenmiştir. Elde edilen sonuçlar, doğum sonu anne sütü ve emzirme sürecini olumsuz etkileyen faktörlere yönelik bilgi vermesi ve gerekli önlemlerin alınabilmesi bakımından önemlidir.

Yoğun bakım üniteleri hastaları hem fiziksel hem de psikolojik açıdan olumsuz etkileyebilir. ${ }^{20}$ $\mathrm{Bu}$ araştırmada, doğum servisinde yatan lohusaların kadın doğum yoğun bakım servisinde yatanlara göre, doğum sonu bebeklerini sadece anne sütü ile besleme oranları daha yüksek bulunmuştur. Yoğun bakım ünitelerinde hastalara çok fazla girişim yapılması, hasta mahremiyetinin sağlanamaması, hastanın yakınlarından destek alamaması, tıbbi cihazlardan kaynaklanan gürültülü ortam ve buna bağlı olarak yaşanan uykusuzluk gibi olumsuzluklar hastalarda strese ve bu stres sonucunda bazı problemlerin yaşanmasına neden olabilir. ${ }^{20,21}$ Yoğun bakım ünitelerindeki tüm bu olumsuzlukların yanı sıra, sağlık personellerinin aşırı iş yükü ve daha çok hastalığın tedavisi odaklı çalışmalarına bağlı olarak hastalara gösterdikleri tutum ve davranışlar da yoğun bakımda yatan hastaları olumsuz yönde etkilemektedir. ${ }^{22}$ Araştırmanın bulguları doğrultusunda; lohusaların yoğun bakımda yatma gerekçesine bağlı olarak, 
bebeklerinin çoğunlukla yenidoğan yoğun bakımda bulunması, bazı durumlarda bebekte de tıbbi sorunların olması ve lohusaların yanlarında destek alabilecekleri yakınlarının bulunmaması gibi nedenlerden dolayı emzirmeye geç başladıkları düşünülmektedir. $\mathrm{Bu}$ nedenle yoğun bakım ünitesinde çalışan sağllk personellerinin, bebeğe anne sütü verme konusunda çaba göstermeleri ve anneleri desteklemeleri son derece önemlidir.

Hastaların hastaneye kabulünden taburcu edilmesine kadar geçen süre hasta yatış süresi olarak tanımlanmaktadır. ${ }^{23}$ Araştırmada, yatış süresi bir gün olan lohusaların yatış süresi iki veya üç gün olanlara göre doğum sonu bebeklerini sadece anne sütü ile besleme oranları daha yüksek bulunmuştur. Hastane yatış süresinin uzaması, özellikle yoğun bakım ünitesinde kalan anneler için, bebeklerini sıklıkla emzirememesine ya da sütünü, süt sağma pompaları ile boşaltmak zorunda kalmasına, ayrıca anne-bebek bağlanmasında gecikmelere neden olabilmektedir. Süt pompaları fizyolojik emzirme ile aynı etkiye sahip olamamakla birlikte, annelerde strese ve süt salınımının azalmasına neden olabilir. ${ }^{24}$ Ayrıca yatış sürelerinin uzaması emzirme dışında hastane enfeksiyonları gibi komplikasyonlara da neden olabilmektedir. ${ }^{23}$ Zorunlu nedenlerden dolayı annelerin hastanede yatış sürelerine müdahale edilemeyebilir ancak, hastanelerde özellikle bebeğin yaşamının ilk günlerinde emzirmenin başlatılması ve sürdürülmesi, annelerin emzirmeye teşvik edilmesi ve desteklenmesi yönünde faaliyetler yapılabilir.

Lohusaların çocuk sayısı ile bebeklerini anne sütü ile besleme durumları arasındaki ilişki net değildir. Bu araştırmada, çocuk sayısı birden fazla olan lohusaların, bir çocuğu olanlara göre doğum sonu bebeklerini sadece anne sütü ile besleme oranları daha yükssek bulunmuştur. Yeşilçiçek Çalık ve ark. (2017) çalışmalarında iki ve daha fazla çocuğu olan annelerin tek çocuğu olanlara göre doğum sonu ilk 6 ay anne sütü ile beslenme yüzdelerinin daha yüksek olduğunu bildirmiştir. ${ }^{14}$ Ünsal ve ark. (2005) çalışmalarında tek çocuğu olan annelerin birden fazla çocuğu olanlara göre bebeklerini anne sütü ile besleme yüzdelerinin daha yüksek olduğunu saptamıştır. ${ }^{25}$ Ahi ve ark. (2019) ise çalışmalarında çocuk sayısı ile ilk bir saat içinde emzirmeye başlama durumu arasında ilişki bulunmadığını bildirmiştir. $^{26} \mathrm{Bu}$ farklılıkların araştırma yapılan örneklem gruplarının doğum sonu bebeklerini anne sütü ile besleme durumlarının farklı zamanlarda araştırılmasından kaynaklanabileceği düşünülmektedir. Ayrıca bu araştırma sonuçları, daha önce emzirmeyi deneyimlemiş olmanın lohusalarda doğum sonu bebeğini sadece anne sütü ile beslemede etkili bir faktör olabileceğini düşündürmektedir.
Araştırmada, normal doğum yapan lohusalarda, sezaryen ile doğum yapanlara göre doğum sonu bebeklerini sadece anne sütü ile besleme oranları daha yüksek bulunmuştur. Literatürde doğum şeklinin emzirmeyi başlatma ve sürdürme üzerinde etkisinin olmadığını belirten çalışmalar bulunmakla birlikte ${ }^{14,18,27}$ kadınların doğum şeklinin emzirmeye başlama sürelerini etkilediğini gösteren çalışmalar da bulunmaktadır. ${ }^{17,28,29}$ Doğumların büyük çoğunluğu sağlık kurumlarında, nitelikli sağlık çalışanları tarafindan gerçekleştirilmesine rağmen, çoğu yenidoğan yaşamın ilk bir saatinde anne sütü ile beslenmeye başlatılamamaktadır. ${ }^{30}$ Doğum şekli ile ilk emzirme sürelerinin karşılaştırıldı $\breve{g}_{1}$ çalışmalarda; Akyüz ve ark. (2007), normal doğum yapan annelerin ilk saatlerde sezaryen olan annelerin ise ilk 2-4 saat içinde bebeklerini emzirdiklerini ${ }^{17}$; Y Ylmaz ve ark. (2017) normal doğum yapan annelerin \% 76.8'inin ilk saat içinde anne sütüne başlarken, sezaryen grubunda bu oranın \% 44.6 olduğunu belirtmiştir. ${ }^{28} \mathrm{Bu}$ araştırmada doğum sonrası bebeklerde, ilk 30 dakikada içinde anne sütü ile beslemeye çok az sayıda anne (\%3) başladığı ve bunların tamamının normal doğum yaptığ1, ancak sayının çok az olması sebebiyle annelerin doğum şekillerinin emzirme süresine etkisinin olup olmadığ 1 belirlenememiştir. İlgili hastanenin kadın doğum dal hastanesi olması, hasta profilinin daha çok sosyo-ekonomik düzeyi düşük bireylerden oluşması ve yabancı uyruklu hasta popülasyonun fazla olması gibi nedenler hastanenin yoğunluğunu arttırmaktadır. Araştırma bulgularına göre normal doğum sonrası ilk 30 dakika içerisinde anne sütü ile emzirmeye başlayanların sayısının çok az olmasının ilgili hastanenin bebek dostu hastanesi emzirme politikasının olmasına rağmen, hastane yoğunluğuna bağlı eleman sayısındaki olası yetersizlikten kaynaklandığı düşünülmektedir. Hannula ve ark. (2008) tarafindan yapılan sistematik derlemede annelerin gebelik, doğum ve doğum sonrası dönemlerde desteklendiklerinde emzirmenin olumlu yönde arttığı bildirilmiştir. ${ }^{31}$ Araştırmada normal doğum yapan lohusaların sezaryen doğum yapanlara göre sadece anne sütü ile besleme oranının yüksek olması, sezaryen olan annelerde hem ameliyat sonrası uyanma dönemi hem de ağrılara bağlı uygun pozisyon alamamaları nedeniyle emzirmeye geç başlamalarından kaynaklanabilir. Kadınların gebelik sürecinde, emzirme de dahil olmak üzere doğum sonrası döneme yönelik eğitim almaları sağlanarak, ayrıca doğum sonrası, hem sağlik personeli hem de yakınları tarafından desteklenerek, emzirmenin daha erken dönemde başlatılabileceği ve devamında sürdürülebileceği düşünülmektedir.

$\mathrm{Bu}$ araştırmada, doğum sonu bakıma ilişkin eğitim alan lohusaların, eğitim almayanlara göre doğum sonu bebeklerini sadece anne sütü ile 
besleme oranları daha yüksek bulunmuştur. Lin ve ark. (2008) tarafından yapılan çalışmada, doğum öncesi emzirme eğitimi alan annelerin, eğitim almayan annelere göre emzirme bilgisinin daha yüksek olduğu ve doğum sonu ilk aydan itibaren emzirme problemleri ile daha az karşılaştıkları belirtilmiştir. ${ }^{11}$ Stuebe ve Bonuck (2011) çalışmalarında, doğum öncesi dönemde anneler açısından emzirmenin önemi üzerinde durulmasının emzirmenin devamlılığı açısından etkili olduğunu belirtmişlerdir. ${ }^{12}$ Dyson ve ark. (2005) tarafından yapılan, emzirme eğitimlerinin emzirmeye başlama oranlarına etkisinin incelendiği sistematik derlemede, eğitimin şekli nasıl olursa olsun emzirme eğitimi alan kadınlarda postpartum dönemde emzirmeye başlama oranları daha yüksek bulunmuştur. $^{32}$ Imdad ve ark. (2011) yaptıkları sistematik derlemede doğum öncesi danışmanlığın doğum sonu 4-6.haftaya kadar önemli bir etkisinin olduğunu belirtirken, hem doğum öncesi hem de doğum sonrası dönemde yapılan emzirme danışmanlığının ilk 6 ay sadece anne sütü ile beslemede önemli katkıları olduğunu belirtmiştir. ${ }^{33}$ Emzirmenin başarılı olabilmesi için kadınların doğum öncesi dönemle birlikte sonu döneme yönelik kaliteli bakım ve nitelikli destek alması gerekmektedir. Nitelikli destek, kadınları güçlendirir ve daha iyi emzirme oranlarına dönüşen güven oluşturur. ${ }^{30}$ Gebelik, doğum ve doğum sonu (ilk saat içinde emzirmenin başlatılması da dahil) döneme ilişkin kadınların ve yenidoğanların kaliteli bakım hizmeti ebe yönetiminde iyi düzenlenmiş sürekli bakım ile sağlanabilir.

\section{Araștırmanın Sınırlılıkları}

$\mathrm{Bu}$ araştırmanın bazı sınırlılıkları bulunmaktadır. Çalışmanın yapıldığı hastanenin uygulaması gereği, yoğun bakım ünitesinde yatan annelerin bebekleri gözlem amaçlı da olsa anne yanına verilmeden doğrudan birinci basamak yenidoğan ünitesine alınmaktadır. Bu nedenle yoğun bakım ünitesinde yatan annelere ilk saatlerde emzirme başlatılamadı̆̆ 1 için bu sonuçlar tüm yoğun bakım ünitesinde yatan hastalar için genellenemez. Ayrıca araştırmada anne sütü ile emzirmeye başlama saati olarak sadece ilk yarım saat ve sonrası alındığ için, doğum sonrası ilk birinci saatteki emzirmeye başlama saatleri tam olarak değerlendirilememiştir.

\section{SONUÇ VE ÖNERİLER}

$\mathrm{Bu}$ araştırmada, doğum sonu dönemde doğum servisinde yatanların, hastanede yatış süresi kısa olanların (1 gün), çocuk sayısı birden fazla olanların, normal doğum yapanların ve doğum sonu bakıma ilişkin eğitim alan lohusaların doğum sonu dönemde bebeklerini sadece anne sütü ile besleme oranlarının daha yüksek olduğu belirlenmiştir.
Annelerin nitelikli doğum öncesi bakım almaları sağlandığında, emzirmenin yaşamın ilk saatinde başlatılması ve bebeğin doğumdan hemen sonra ve devamında (ilk 6 ay) sadece anne sütü ile beslenmesinin sürdürülmesi sağlanabilir. Anne sütünün yenidoğan sağlığ1 üzerine etkileri düşünüldüğünde, emzirmeyi olumsuz yönde etkileyen faktörlerin çalışmalarla daha net olarak ortaya çıkarılması ve iyileştirmelerinin yapılması önem arz etmektedir. Ayrıca ebelerin kadınlara doğum sonu döneme yönelik emzirmenin ilk saatlerde başlatılmasını ve sadece anne sütü ile beslenmenin sürdürülmesini kapsayan konularda danışmanlık yapmaları ve onları desteklemeleri büyük öneme sahiptir.

\section{Çıkar çatışması}

Yazarlar arasında çıkar çatışması yoktur.

\section{Teşekkür}

Çalışmaya katılan tüm katılımcılara teşekkür ederiz

\section{KAYNAKLAR}

1. World Health Organization. Reproductive health. [cited 2020 July 15]. Available Del Ciampo LA, Del Ciampo IRL. Breastfeeding and the Benefits of Lactation for Women's Health. Rev Bras Ginecol Obstet 2018;40(6):354-9.

2. Irmak N. Anne sütünün önemi ve ilk 6 ay sadece anne sütü vermeyi etkileyen unsurlar. J Turkish Fam Physician 2016;7(2):27-31.

3. Topal S, Çınar N, Altınkaynak S. Emzirmenin anne sağlığına yararları. J Hum Rhythm 2017;3(1):25-31.

4. Ateşağaoğlu P, Mete M, Gökçay G, Tamay Z, Yetim A. Anne Sütü ile Beslenmenin Çocuk Ruh Sağlığına Etkileri. Cocuk Derg 2013;13(3):101-8.

5. Gölbaşı Z, Koç G. Kadınların postpartum ilk 6 aylık süredeki emzirme davranışları ve prenatal dönemdeki emzirme tutumunun emzirme davranışları üzerindeki etkisi. Hacettepe Üniversitesi Hemşirelik Fakültesi Derg 2008;15(1):16-31.

6. World Health Organization (WHO). Health topics/Breastfeeding. Erişim: https://www.who.int/healthtopics/breastfeeding\#tab=tab 2. Erişim tarihi: 24 Şubat 2020.

7. United Nations International Children's Emergency Fund (UNICEF). BREASTFEEDING A Mother's Gift, for 
Every

Child

Erişim:

https://data.unicef.org/resources/breastfeedinga-mothers-gift-for-every-child/. Erişim tarihi: 24 Şubat 2020.

8. World Health Organization (WHO). Facts in pictures/Breastfeeding Erişim: https://www.who.int/features/factfiles/breastfee ding/en/. Erişim trarihi: 24 Şubat 2020.

9. Hacettepe Üniversitesi Nüfus Etütleri Enstitüsü. Türkiye Nüfus ve Sağlık Araştırması (TNSA) 2018. Erişim:http://www.hips.hacettepe.edu.tr/tnsa20 18/rapor/TNSA2018_ana_Rapor.pdf. Sayfa No: 144-145. Erişim tarihi: 24 Şubat 2020.

10. Uyar Hazar H, Uzar Akça E. Doğum Sonrası Erken Dönemde Emzirme Problemi: Olgu Sunumu. Sağlık ve Toplum 2017;27(3):64-70.

11. Lin S, Chien L, Tai C, Lee C. Effectiveness of a prenatal education programme on breastfeeding outcomes in Taiwan. J Clin Nurs 2008;17(3):296-303.

12. Stuebe AM, Bonuck K. What predicts intent to breastfeed exclusively? Breastfeeding knowledge, attitudes, and beliefs in a diverse urban population. Breastfeed Med 2011;6(6):413-20.

13. Arça G, Işık HK. Anne Sütü ve Emzirmeye İlişkin Ebe ve Hemşirenin Rolü. Sağlık Bilim Üniversitesi Hemşirelik Derg 2019;1(3):221-8.

14. Yeşilçiçek Çalık K, Coşar Çetin F, Erkaya R. Annelerin emzirme konusunda uygulamaları ve etkileyen faktörler. Gümüşhane Üniversitesi Sağlık Bilim Derg. 2017;6(3):80-91.

15. Cangöl E, Hotun Şahin N. Emzirmeyi Etkileyen Faktörler ve Emzirme Danışmanlığı. Zeynep Kamil Tıp Bülteni 2014;45(3):100-5.

16. Bolat F, Uslu S, Bolat G, Bülbül A, Arslan S, Çelik M, Cömert S, Nuhoğlu A. İlk altı ayda anne sütü ile beslenmeye etki eden faktörler. Çocuk Dergisi 2011;11(1):5-13.

17. Akyüz A, Kaya T, Şenel N. Annenin emzirme davranışının ve emzirmeyi etkileyen durumlarin belirlenmesi. TSK Koruyucu Hekimlik Bülteni 2007;6(5):331-5.

18. Küçükoğlu S, Çelebioğlu A, Coşkun D. Yenidoğan kliniğinde bebeği yatan annelerin postpartum depresyon belirtileri ve emzirme özyeterlilik düzeylerinin belirlenmesi.
Gümüşhane Üniversitesi Sağlı Bilim Derg 2014;3(3):921-32.

19. Gönenli S, Ayar Kocatürk A, Yeşilçiçek Çalık K. Normal Doğum Yapan Primipar Annelerin Erken Doğum Sonu Dönemde Emzirme Başarısı ve Etkileyen Faktörler. STED/Sürekli Tıp Eğitimi Derg 2019;28(3):191-200.

20. Karahan E, Akın N, Çelik S. Yoğun bakımda yatan hastaların deneyimleri ve aile gereksinimlerinin incelenmesi. Adryaman Üniversitesi Sağlık Bilim Derg 2020;6(2):1409.

21. Çam R, Şahin B. Yoğun Bakım Ünitelerinde Yatan Hastaların Deneyimleri ve AnksiyeteDepresyon Durumları. Hemşirelik Bilimi Derg 2018;1(1):10-4.

22. Yılmaz E, Arslan S. Acil kritik yoğun bakımda yatan hastaların incelenmesi. Selçuk Tıp Derg 2015;31(3):113-7.

23. Öngel V, Duran E. Hasta Yatış Süreleri Açısından Cerrahpaşa Tıp Fakültesi Hastanesi Çocuk Nefroloji Servisi'nin 2012 Yilı Analizi. International Conference On Eurasian Economies 2015: 732-5.

24. Altuntaş N. Yenidoğan yoğun bakım ünitesine yatış emzirme sürecini nasıl etkiliyor? Pamukkale Tip Derg 2020;13(3):579-86.

25. Ünsal H, Atlıhan F, Özkan H, Targan Ş, Hassoy H. Toplumda anne sütü verme eğilimi ve buna etki eden faktörler. Çocuk Sağlığı ve Hast Derg 2005;48(3):226-33.

26. Ahi S, Borlu A, Balcı E, Günay O. Bebek Dostu Bir Hastanede Doğum Yapan Annelerin Doğumdan Sonra İlk Bir Saatte Emzirmeye Başlama Durumları ve İlişkili Faktörler. Ahi Evran Med J 2019;3(2):41-7.

27. Burns C, Dunn A, Brady M, Starr N, Blosser C. Pediatric Primary Care. 5. Bask1. Elsevier yayınları; 2013:180-200.

28. Y1lmaz E, Öcal FD, Vural Y1lmaz Z, Ceyhan M, Kara OF, Küçüközkan T. Emzirmeye başlama ve sadece anne sütüyle besleme: Bebek dostu bir hastanede doğum yapmış annelerin yaklaşımlarını etkileyen faktörler. Turkish J Obstet Gynecol 2017;14(1):1-9.

29. Cantürk D, Akgün Kostak M. Vajinal doğum yapan ve sezaryen operasyonu geçiren annelerin ilk emzirme davranışları, emzirme öz-yeterlilik düzeyleri ve etkileyen faktörler. 
Mersin Üniversitesi Sağlık Bilim Derg 2020;13(3):382-94.

30. United Nations International Children's Emergency Fund (UNICEF). CAPTURE THE MOMENT: Early initiation of breastfeeding: The best start for every newborn. Erişim: https://cdn.who.int/media/docs/defaultsource/nutritionlibrary/breastfeeding/unicefwho-capture-the-moment-eibf2018.pdf?sfvrsn=587210cf $2 \&$ download=true. Erişim tarihi: 01 Mart 2021.

31. Hannula L, Kaunonen M, Tarkka M. A systematic review of professional support interventions for breastfeeding. J Clin Nurs 2008;17(9):1132-43.

32. Dyson L, McCormick F, Renfrew MJ. Interventions for promoting the initiation of breastfeeding. Cochrane Database of Systematic Reviews 2005;(2).Art. No: CD001688.

33. Imdad A, Yakoob MY, Bhutta ZA. Effect of Breastfeeding promotion interventions on breastfeeding rates with special focus on developing countries. BMC Public Health 2011;11(3):24. 